\title{
ÇOKKÜLTÜRLÜLÜK ALGI ÖLÇEĞİ: GEÇERLİK VE GÜVENIRLIK ÇALIŞMASI
}

\author{
MULTICULTURALISM PERCEPTION SCALE: RELIABILITY AND \\ VALIDITY STUDY
}

\section{DOI:10.17755/esosder.11595}

\section{Mehmet Fatih AYAZ ${ }^{1}$}

\section{$\ddot{O} \mathbf{z}$}

$\mathrm{Bu}$ araştırmada öğretmen adaylarının çokkültürlülük ile ilgili algılarını belirlemek amacıyla geliştirilen Çokkültürlülük Algı Ölçeği’nin geçerlik ve güvenirlik çalışması yapılmıştır. Bunun için 2014-2015 EğitimÖğretim yılında Dicle Üniversitesi Ziya Gökalp Eğitim Fakültesi son sınıf öğrencisi olan toplam 194 öğretmen adayıyla çalışılmıştır. Öncelikle KMO ve Bartlett testleriyle verilerin faktör analizine uygun olduğu belirlenmiştir. Daha sonra elde edilen veriler açımlayıcı faktör analizi ve doğrulayıcı faktör analizlerine tabi tutulmuştur. Yapılan analizler sonucunda ölçeğin, toplam varyansın \%43.127'sini açıklayan tek boyut altında toplandığı belirlenmiştir. Maddelerin faktör yükleri incelendiğinde bir madde dışında tüm maddelerin .30 ve üzeri faktör yüküne sahip olduğu görülmüsstür. Faktör yükü düşük olan madde çıkarıldığında 25 maddeden oluşan bir yapı elde edilmiştir.Uyum geçerliği ve güvenirlik analizleri sonucunda elde edilen bulgular, ölçeğin çokkültürlülük algılarını belirlemede geçerli ve güvenilir bir ölçek olduğu söylenebilir.

Anahtar Kelimeler: Çokkültürlülük, Öğretmen Adayları, Algı Ölçeği, Geçerlik, Güvenirlik.

\begin{abstract}
In this research, the study about reliability and validity of Multiculturalism Perception Scale that was developed to measure the sensations of teacher candidates about multiculturalism was carried out.. For this, it was studied with 194 teacher candidates who were senior students in Ziya Gökalp Education Faculty of Dicle University in 2014-2015 education year. Firstly it was determined with KMO and Bartlett tests that it was agreeable with factor analysis of data. Then, the data obtained was subjected to exploratory factor analysis and confirmatory factor analysis. As a result of analyses made, it was determined that scale could be gathered under single dimension that explains $\% 43.127$ of total variance. It was observed that all materials, except for one, have stated .30 and over factor loads when the factor loads of materials were examined. A structure consisted of 25 materials was obtained after the material which had less factor load was removed. With the findings obtained as a result of concurrent validity and reliability analysis, it was determined that the scale is valid and reliable to measure multiculturalism sensations.
\end{abstract}

Keywords: Multiculturalism, Pre-service Teachers, Perception Scale, Reliability, Validity.

\footnotetext{
${ }^{1}$ Dicle Üniversitesi Z.G.Eğitim Fakültesi, mf_ayaz@hotmail.com
} 


\section{GİRIŞ}

Bir toplumda, farklı kültürlerin birlikte bulunması çok eski zamanlardan beri söz konusu iken özellikle göçler ve küreselleşmenin etkisiyle birlikte kültürler arasında ciddi bir etkileşimin başladığı gözlemlenmeye başlanmıştır. Kültür, bir halkın yaşama tarzıdır (Turhan, 1969). Milletleri millet yapan kuvvet ve inançların, kültür adı altında toplandığı söylenebilir. Özetle; kültür davranış kalıpları, tutumlar, normlar, değerler, iletişim biçimleri, dil, inançlar, eylemler, sağlık koşulları, uygarlık, üretim, eğitim ürünü gibi birçok öğeyi içerisinde barındıran bir yapıya sahiptir (Doytcheva, 2005; Güvenç, 1994; San, 1983). Kültürel özelliklerin bir toplumda yaşatılması ve yaşanmasına imkân tanınması demokrasinin önemli unsurlarından birini oluşturmaktadır.

Demokrasiyi sağlamanın en önemli koşullarından biri, toplumu oluşturan kültürlerin bir arada bulunup yaşamasını demokratik yollarla sağlamaktan geçmektedir. Günümüz dünyasında birçok ülke, çok dinli, çok etnikli, çok dilli ve çok kültürlü bir yapıda bulunmaktadır (Portes ve Rumbaut, 2006). Bu farklılıkların, aynı toplumda beraber yaşamasının sağlanması toplumsal huzur açısından önem arz etmektedir. $\mathrm{Bu}$ durumu sağlayacak faktörlerden en önemlilerinden biri çokkültürlülük anlayışıdır. Genel olarak çokkültürlülük; rrk, etnik yapı, dil, cinsel yönelim, cinsiyet, yaş, engelli olma, sosyal sınıf, eğitim, dinsel yönelim ve diğer kültürel boyutların farkına varılması olarak ifade edilebilir (Banks, 2014). Eğitim, toplumun kültürel değerlerini ve davranış örneklerini yeni nesillere aktarma işlevi ile önemli bir misyon üstlenmektedir. Eğitim, bir ülkenin insan profilini belirleyen, kültürü başta olmak üzere toplumun tüm dokusu üzerinde etkileri bulunan, mevcut olan yapıyı korumada olduğu kadar olası değişimleri de belirleyebilen en önemli süreçlerden biridir (Asan, 2014). Bu nedenle son yıllarda, eğitimle ilgili çalışmalarda çokkültürlü eğitim kavramının önemli bir yer tuttuğu görülmektedir.

Çokkültürlü eğitim, öğrencilerin cinsiyetine, sosyal statüsüne, etnik, 1rksal veya kültürel karakteristiklerine bakmaksızın tüm öğrencilerin öğrenmek için okulda eşit firsatlara sahip olması düşüncesine dayanır (Banks, 2014). Çokkültürlü eğitimin başarıya ulaşabilmesi için eğitimin asli unsurlarının başında gelen öğretmenlerin de bu eğitime uygun özelliklere sahip olması gerekmektedir. Ancak yapılan araştırmalarda gerekli altyapıya sahip olmayan birçok öğretmenin farklı kültürlerden olan öğrenciler için öğrenme ortamını oluşturma konusunda yeterli olmadığı görülmektedir (Gay, 2002). Bu problemlerin ortadan kaldırılabilmesi için öğretmenlere ve öğretmen adaylarına farklı kültürlerden gelen öğrencilere yönelik öğrenme ortamlarının tasarlanması için gerekli olan becerilerin kazandırılmasının önemli olduğu düşünülmektedir.

Çokkültürlü eğitimde kültürlerarası yeteneğe sahip bir öğretmen basmakalıp ön yargılardan, ayrımcılıktan ve ırkçı tavırlardan uzak durur. Dolayısıyla çokkültürlü eğitim için öğretmenlerin de kültürlerarası duyarlılığa sahip olmaları gerekmektedir. Kültürel görecelilik felsefesini benimsemiş olmaları çokkültürlü eğitim verebilmede yeterlilik için ön koşuldur (Akıncı Çötok, 2010). Bu felsefede, her kültürün özel olduğunu benimsemek ve diğer kültürlerin değerleriyle karşılaştırmamak temel anlayıştır (Portera, 2008). Kültür olarak farklı çocukların eğitim firsatı ve eğitim başarısı konularında aleyhlerine olan bu eşitsizlik durumunu ortadan kaldırmak için öğretmenler, sınıf ortamında mümkün olduğunca kültürel olarak farklı olan öğrencilere hitap edecek şekilde çeşitli kaynaklar, materyaller, öğretme stratejileri, teknikleri ve değerlendirme yöntemleri kullanmalıdırlar (Gay, 2010).

Öğretmenlerin çokkültürlü eğitim ile ilgili bilgi, anlayış ve düşüncelerinin genel olarak öğretmenlik eğitimi aldıkları zamanlarda oluştuğu söylenebilir. Öğretmenlik eğitimi döneminde elde edilen bilgilerin ve anlayışların öğretmen adaylarının çokkültürlülük algılarını belirlemede çok önemli olduğu düşünülmektedir. Ayrıca yapılan literatür taraması 
kapsamında konu ile ilgili öğretmen adaylarına yönelik olarak geliştirilen bir ölçeğe rastlanılmamıştır. Bu nedenle bu çalışmada öğretmen adaylarının çokkültürlülük algılarını ölçmek amacıyla geliştirilen Çokkültürlülük Algı Ölçeği’nin(ÇAÖ) güvenirlik ve geçerlik çalışması yapılmıştır.

\section{YÖNTEM}

\section{Çalışma Grubu}

Araştırma, 2014-2015 Eğitim-Öğretim Y1lı bahar dönemi sonuna doğru Dicle Üniversitesi Ziya Gökalp Eğitim Fakültesi son sınıf öğrencileri üzerinde gerçekleştirilmiştir. Araştırmaya toplam 217 öğretmen adayı katılmıştır. Ancak 23 katılımcının ölçeği, eksik doldurulduğundan dolayı analize tabi tutulmamıştır. Böylece çalışma grubu toplam 194 öğretmen adayından oluşmuştur. Çalışma grubuna ait betimleyici istatistikler Tablo 1'de verilmiştir.

Tablo 1. Öğretmen Adaylarına Ait Betimleyici İstatistikler

\begin{tabular}{lccc}
\hline Değişkenler & & n & \% \\
\hline \multirow{2}{*}{ Cinsiyetiniz } & Kadın & 124 & 64 \\
& & & \\
& Erkek & 70 & 36 \\
\hline \multirow{3}{*}{ Branşınız } & Sınıf & 38 & 19,5 \\
& Okulöncesi & 32 & 16,5 \\
& Tarih & 16 & 8,2 \\
& Coğrafya & 15 & 7,7 \\
& Matematik & 20 & 10,3 \\
& Fen ve & 17 & 8,8 \\
& Teknoloji & & 15,5 \\
& Türkçe & 30 & 13,5 \\
\hline
\end{tabular}

\section{Veri Toplama Aracı}

Öğretmen adaylarının çokkültürlülük ve çokkültürlü eğitim ile ilgili algılarını belirlemek amacıyla hazırlanan "Çokkültürlülük Alg1 Ölçeğini (ÇAÖ)"oluşturmak için öncelikle çokkültürlülük ve çokkültürlü eğitim ile ilgili literatür incelenmiş ve çokkültürlülük anlayışa sahip olma nitelikleri belirlenmiştir. Bununla birlikte çokkültürlü eğitim için gerekli olan özellikler listelenerek bir madde havuzu oluşturulmuştur. Ayrıca Türkiye'de çokkültürlülük ile ilgili hazırlanmış olan ölçekler incelenmiştir. İncelenen ölçeklerden bazı maddeler seçilmiştir. $\mathrm{Bu}$ maddelerden bazıları aynen alınmış, bazıları ise değiştirilerek kullanılmıştır. Ponteretto, Baluch, Greig ve Rivera (1998) tarafindan geliştirilen ve Yazıcı, Başol ve Toprak (2009) tarafından Türkçeye uyarlanan öğretmenlerin çokkültürlü eğitime yönelik tutumlarını belirlemek için hazırladıkları ölçekten, Başbağ ve Kağnıcı'nın (2011) öğretim elemanları üzerinde çalışarak hazırladıkları Çokkültürlü Yeterlik Algıları Ölçeği'nden, Polat'ın (2012) okul müdürlerinin çokkültürlülüğe ilişkin tutumlarını ölçmek için hazırladığı ölçekten, Koç Damgacı ve Aydın'ın (2013) öğretim üyelerinin çokkültürlü eğitime yönelik tutumlarını ölçmek için hazırladıkları ölçekten yararlanılmıştır.

Çokkültürlülük Algı Ölçeği için ilk olarak toplam 29 madde hazırlanmıştır. Daha sonra araştırmacı tarafından yapılan incelemeler sonucunda 3 madde gereksiz olduğu ya da benzer madde bulunduğu için çıkarılmıştır. Hazırlanan ölçek iki Türkçe öğretmenine 
inceletilmiş ve gerekli düzeltmelerden sonra son şeklini almıştır. Ölçek beşli likert tipi formatında geliştirilmiştir. Ölçeğe katılma düzeyleri; "Hiç katılmıyorum", "Katılmıyorum", "Kararsızım", "Katılıyorum" ve "Kesinlikle katılıyorum" şeklindedir. Geliştirilen ölçeğin uyum geçerliğini belirlemek amacıyla Yazıcı, Başol ve Toprak'ın (2009) Türkçeye uyarlamış olduğu "Öğretmenlerin Çokkültürlü Eğitim Tutumları Ölçeği” (ÖÇTÖ) kullanılmıştır.

\section{Verilerin Analizi}

ÇAÖ çalışma grubuna uygulandıktan sonra gerekli istatistiksel analizler yapılmıştır. Ölçümlerin yapı geçerliğini belirlemek için Açımlayıcı Faktör Analizi (AFA) yapılmıştır. AFA'dan önce verilerin faktör analizine uygun olup olmadığının belirlenmesi gerektiğinden öncelikle çalışma grubunun büyüklügüne bakılmıştır. Bu konuda çeşitli uzmanlar tarafından farklı ölçütler belirlenmiştir. Örneğin, Cattell (1978) faktör analizi çalışmalarında, ölçekteki madde sayısının 3 ile 6 katı kadar katılımcının çalışma grubuna dâhil edilmesi gerektiğini belirtmektedir. Ferguson ve Cox (1993) faktör analizi çalışmalarında, ölçüt olarak gerekli katılımcı sayısının en az 100 olduğunu belirtmektedirler. Buna göre çalışmada 194 katılımcının olmasının faktör analizi için yeterli olduğu görülmektedir. Çalışma grubunun büyüklüğünden sonra verilerin faktör analizine uygun olup olmadığını belirlemek için KaiserMayer-Olkin (KMO) değerinin ve Bartlett testinin belirlenmesi gerekir. Faktör analizi için KMO'nun .60'tan yüksek ve Bartlett testinin istatistiksel olarak anlamlı olması gerekmektedir (Büyüköztürk, 2014).

AFA'da bulunan faktör analiz türlerinden temel bileşenler analizinin, diğer faktör analiz tekniklerine göre psikometrik açıdan daha güçlü ve potansiyel faktör belirsizliği sorunları ile baş etmede daha etkili olabileceği düşünüldüğü için (Tabachnick ve Fidell, 2007) bu çalışmada temel bileşenler analizi kullanılmıştır. AFA ile faktörler belirlenirken boyutların en az \%1 özdeğere sahip olması koşulu aranmaktadır (Büyüköztürk, 2014). Ölçek faktörlerinin birbirleriyle ilişkili olabileceğine yönelik düşünceden dolayı AFA'da direct oblimin döndürme tekniğinin kullanılması daha fazla önerildiğinden (Çokluk, Şekercioğlu ve Büyüköztürk, 2012) çalışmada bu teknik kullanılmıştır. AFA sonuçlarına göre bir maddenin belirlenen boyutta yer alması için faktör yükünün .30 ve üstü olması beklenmektedir (Seçer, 2013). Ayrıca aynı maddenin birden fazla boyutta yer alması durumunda faktör yükleri arasındaki farkın en az .10 olması beklenir, aksi taktirde madde binişik olduğundan ölçekten çıkarılır (Büyüköztürk, 2014).

AFA sonuçlarını doğrulamak ve ölçüm modelini değerlendirmek amacıyla Doğrulayıcı Faktör Analizi (DFA)kullanılmıştır. DFA'da sınanan modelin sınanması amacıyla kullanılan uyum indeksleri,Ki-Kare Uyum Testi, Tahmin Hatalarının Ortalamasının Karekökü (RMSEA), İyilik Uyum İndeksi (GFI), Karşılaştırmalı Uyum indeksi (CFI) ve Düzeltilmiş İyilik Uyum İndeksi (AGFI) olarak belirlenmiştir.

Uyum geçerliği kapsamında, katılımcıların ÇAÖ ile ÖÇTÖ veri toplama araçlarından aldıkları puanlar arasındaki Pearson Momentler Çarpımı Korelasyonu hesaplanmıştır. Korelasyon değerleri .70 ile 1 aralığında olan değerler güçlü ilişkiyi göstermektedir. Ayrıca ÇAÖ kullanılarak elde edilen ölçümlerin güvenirliği Cronbach Alpha, Spearman Brown ve Guttman Split Half değerleri ölçülerek hesaplanmıştır. Araştırmada; AFA, uyum geçerliğii, güvenirlik analizleri için SPSS 20.0, DFA ile ilgili hesaplamalar için ise LISREL 8.54 paket programı kullanılmıştır.

\section{BULGULAR}

Bulgular başlığı altında açımlayıcı faktör analizi, doğrulayıcı faktör analizi, uyum geçerliği ve güvenirlikle ilgili açıklamalar yer almaktadır. 


\section{Açımlayıcı Faktör Analizi (AFA)}

AFA'da KMO değeri .932 bulunmuştur. Bartlett testinin istatistiksel olarak anlamlı olduğu belirlenmiştir $\left(\chi^{2}=883.450, \mathrm{sd}=325\right)$. Bu sonuçlara göre veriler faktör analizine uygun olduğu belirlenmiştir. Daha sonra AFA'da temel bileşenler faktörleştirme tekniği ve direct oblimin döndürme sonucunda toplam varyansın \%59.69'unu açıklayan üç faktörlü bir yapının oluştuğu belirlenmiş̧tir. Ancak bu yapı hem kuramsal temellere uygun olmaması hem de birinci faktörün öz değerinin (11.213) ikinci faktörün özdeğerinin (1.725) 3 katından fazla olması ve toplam varyansı açıklayan yüzdesinin (\%43.127) diğer faktörlere oranla yüksek olması ölçeğin tek faktörlü olmasının kanıtlarıdır (Büyüköztürk, 2014: 147). Bu nedenle ölçek tekrar temel bileşenler faktörleştirme tekniği ile analiz edilmiş olup toplam varyansın \%43.127'sini açıklayan tek faktörlü bir yapı elde edilmiştir. Ölçekteki maddelerden biri (M1) dışında tüm maddelerin .30 üzeri faktör yüküne sahip olduğu görülmüştür. Faktör yükü düşük çıkan madde ölçekten çıkarılmıştır. Sonuç olarak ölçek faktör yükleri .389 ile .809 arasında dağılan 25 maddeden ve tek boyuttan oluşmuştur.

Tablo 2. Maddelerin Faktör Yükleri

\begin{tabular}{|c|c|c|}
\hline Madde & İfade & $\begin{array}{l}\text { Faktör } \\
\text { Yükleri }\end{array}$ \\
\hline M2 & Çevremdeki insanların farklı dille anlaşmaları beni rahatsız etmez. & .637 \\
\hline M3 & İnsanların dini inançları ne olursa olsun onlara saygı duyarım. & .535 \\
\hline M4 & $\begin{array}{l}\text { Öğretmenlerin, her öğrencinin kendi kültürel değerlerini yaşamaları } \\
\text { için firsat vermeleri gerekir. }\end{array}$ & .626 \\
\hline M5 & $\begin{array}{l}\text { İnsanlara sosyal statülerine göre davranılmasının yanlış olduğunu } \\
\text { düşünüyorum. }\end{array}$ & .389 \\
\hline M6 & $\begin{array}{l}\text { Farklı kültürlerin bir arada sorunsuz bir şekilde yaşamasını toplumsal } \\
\text { bir gereklilik olarak görürüm. }\end{array}$ & .696 \\
\hline M7 & $\begin{array}{l}\text { Farklı bölgelerde yaşayan insanların birbirinden farklı davranışlara ve } \\
\text { düşüncelere sahip olabileceklerini anlayışla karşılarım. }\end{array}$ & .648 \\
\hline M8 & $\begin{array}{l}\text { Çokkültürlü eğitimin farklı etnik kökenli öğrenciler için faydalı } \\
\text { olacağına inanıyorum. }\end{array}$ & .757 \\
\hline M9 & $\begin{array}{l}\text { Çokkültürlü eğitim ile toplumda farkl1lıklara bağlı olarak yaşanan } \\
\text { sorunların çözüleceğine inanıyorum. }\end{array}$ & 699 \\
\hline M10 & $\begin{array}{l}\text { Okullarda çokkültürlü eğitim programlarının uygulanmasının eğitimde } \\
\text { fırsat eşitliği sağlayacağına inanıyorum. }\end{array}$ & .793 \\
\hline M11 & Kendimi bir çokkültürlü eğitimci olarak görüyorum. & .514 \\
\hline M12 & Kültürü, benden farklı olan bireylerle empati yaparım. & .728 \\
\hline M13 & $\begin{array}{l}\text { Sadece tek bir kültürün hâkim olduğu sinıflardan ziyade, birden fazla } \\
\text { kültürün eşit haklara sahip olduğu sınıfları tercih ederim. }\end{array}$ & .740 \\
\hline M14 & $\begin{array}{l}\text { Kültürel farklılıkların öğrencilerin akademik başarıları için bir avantaj } \\
\text { olabileceğini düşünüyorum. }\end{array}$ & .532 \\
\hline M15 & $\begin{array}{l}\text { Öğretmen yetiştiren programlarda çokkültürlü eğitimle ilgili derslerin } \\
\text { olmasını isterim. }\end{array}$ & .798 \\
\hline M16 & $\begin{array}{l}\text { Kültürel farklılıklarla bezenmiş bir eğitimin, toplumsal ayrışma } \\
\text { oluşturacağını düşünmüyorum. }\end{array}$ & .627 \\
\hline M17 & $\begin{array}{l}\text { Öğretmenlerin, farklı kültürlerden olan öğrencileri kendi kültürel } \\
\text { kimlikleriyle kabul etmeleri gerektiğini düşünüyorum. }\end{array}$ & .679 \\
\hline M18 & $\begin{array}{l}\text { Eğitim sistemi, ülkede var olan tüm etnik kimliklerin zenginliğini } \\
\text { kapsayacak şekilde olmalıdır. }\end{array}$ & .752 \\
\hline M19 & $\begin{array}{l}\text { Ülkemizde etnik kökene dayalı ayrımcılığın önemli bir sorun olduğunu } \\
\text { düşünüyorum. }\end{array}$ & .576 \\
\hline
\end{tabular}




\begin{tabular}{|c|c|c|}
\hline M20 & $\begin{array}{l}\text { İnsanların yaşlarına bağlı olarak gerçekleştirdikleri davranışlara saygı } \\
\text { duyarım. }\end{array}$ & .540 \\
\hline M21 & Farklı ideolojik fikirlere sahip olan insanlara saygı duyarım. & .735 \\
\hline M22 & $\begin{array}{l}\text { İnsanların etnik kökenlerini endişe duymadan açıklamaları gerektiğini } \\
\text { düşünüyorum. }\end{array}$ & .681 \\
\hline M23 & $\begin{array}{l}\text { Öğretim ortamı, farklı kültürlerdeki öğrencilerin ihtiyaçlarını } \\
\text { karşılayabilecek durumda olmalıdır. }\end{array}$ & .809 \\
\hline M24 & $\begin{array}{l}\text { Çokkültürlü eğitimin, günümüzde göz ardı edilemeyecek kadar önemli } \\
\text { olduğunu düşünüyorum. }\end{array}$ & .768 \\
\hline M25 & $\begin{array}{l}\text { İnsanların, dini inançlarını endişe duymadan açıklamaları gerektiğini } \\
\text { düşünüyorum. }\end{array}$ & .688 \\
\hline M26 & $\begin{array}{l}\text { Öğrencilerin, öğretim ortamında kendilerini kültürlerinden dolayı bir } \\
\text { alt sınıf olarak görmemeleri gerektiğini düşünüyorum. }\end{array}$ & .518 \\
\hline
\end{tabular}

Ölçeğin faktör yapısını grafik üzerinde incelemek amacıyla Şekil 1'de ScreePlot grafiği verilmiştir.

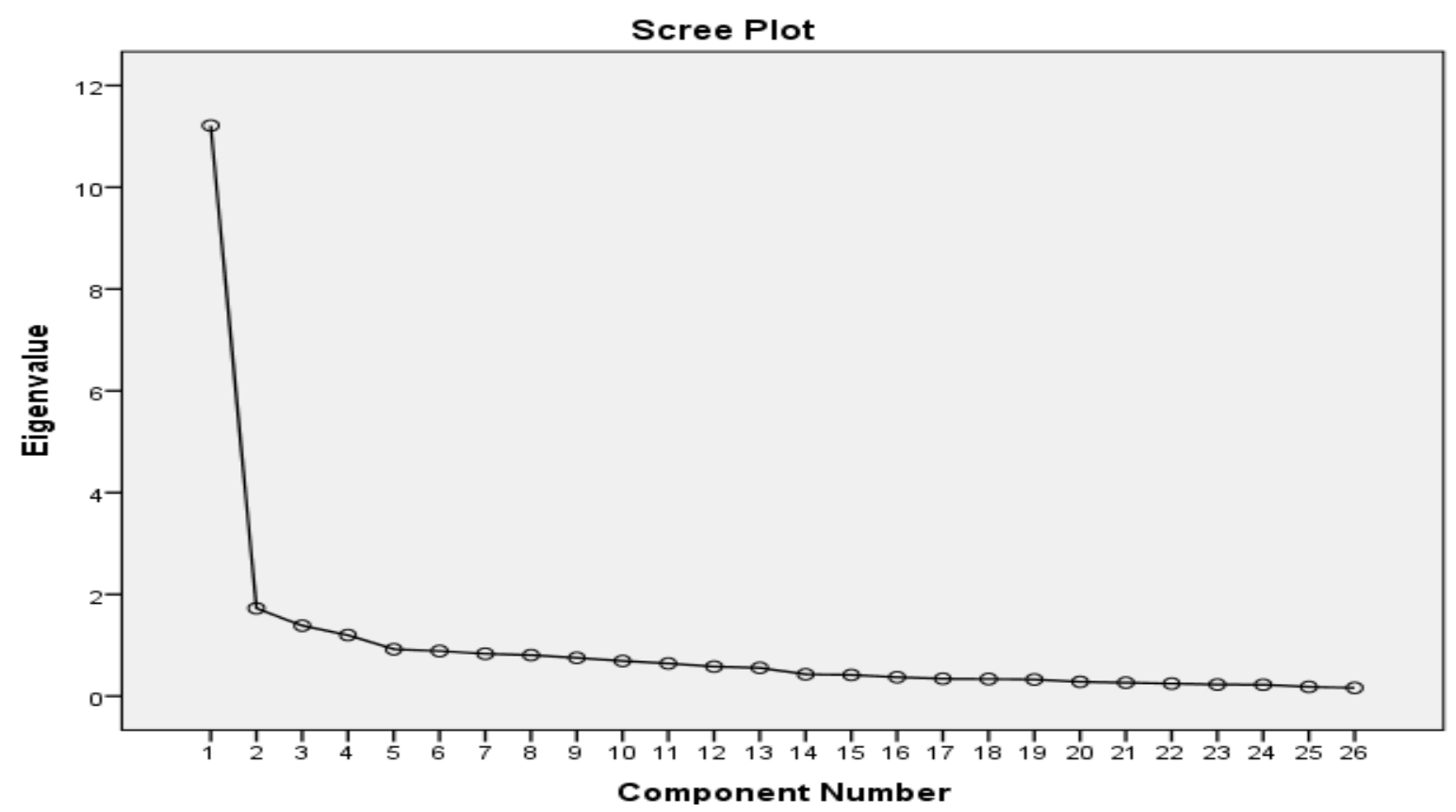

Şekil 1. Maddelerin ScreePlot Grafiği

Maddelerin ScreePlot grafiğine bakıldığında ilk noktadan sonra çok sert bir düşüş olduğu ve diğer noktalar arasındaki uzaklıkların çok kısa olduğu görülmektedir. $\mathrm{Bu}$ durum ölçeğin tek boyutlu olduğunu gösteren bir diğer kanıt durumundadır.

\section{Doğrulayıcı Faktör Analizi (DFA)}

AFA'dan elde edilen sonuçların doğruluğunu test etmek amacıyla DFA kullanılmıştır. ÇAÖ’ya ilişkin maddelerin tek boyut altında toplandığı ve faktör yüklerinin her birinin .30'un üzerinde olduğu Şekil 2'de görülmektedir. 


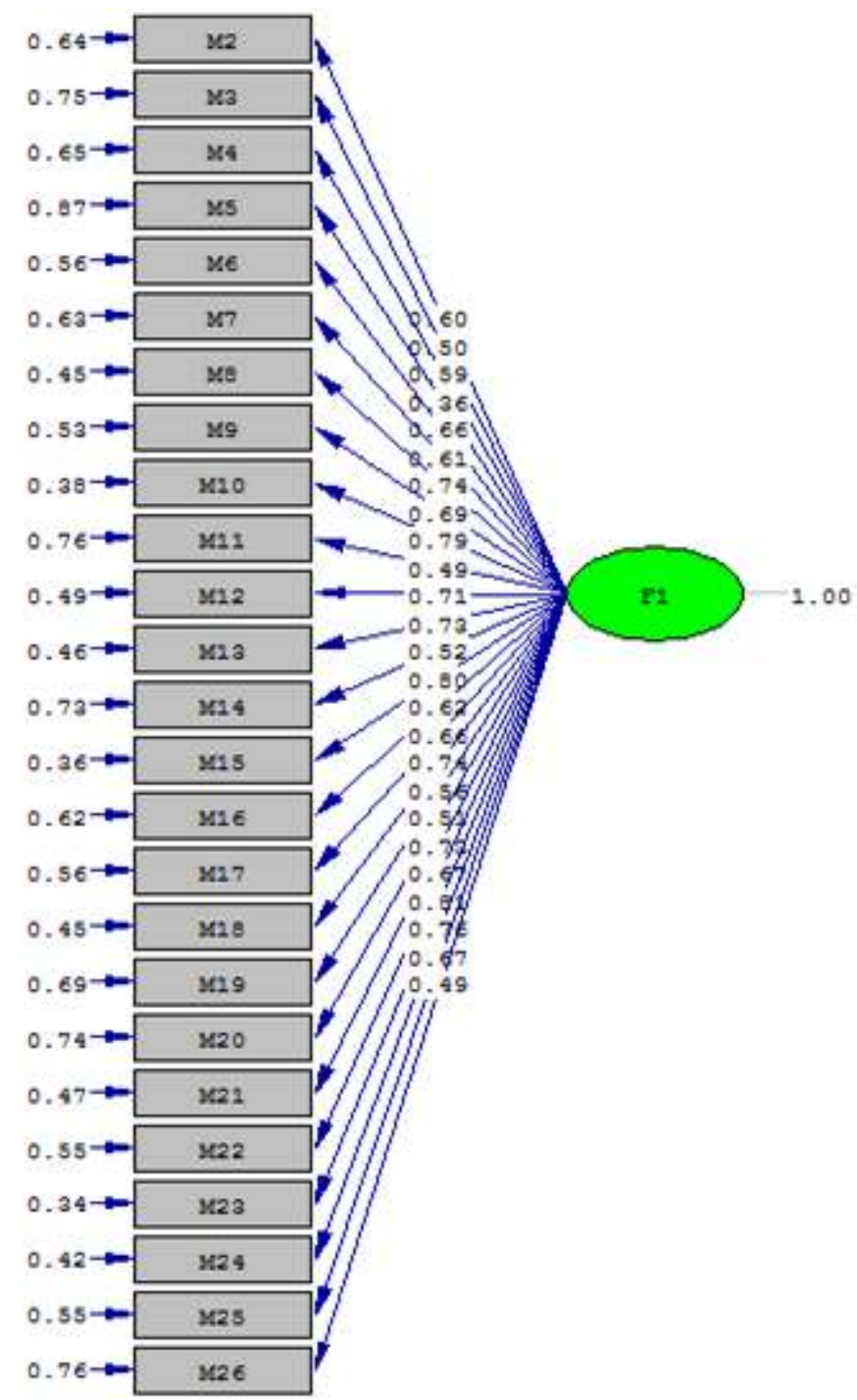

Şekil 2. Çokkültürlülük Algı Ölçeği Path Diyagramı

Şekil 2'de de görüldüğü üzere ölçek, maddelerin faktör yükleri .36 ile .81 aralığında dağılmış $\left(\chi^{2}=937.96\right.$, sd=275) olan tek boyutlu bir ölçektir. DFA bulgularına göre ÇAÖ’ya ilişkin uyum indeks değerleri Tablo 3 'te verilmiştir.

Tablo 3. Uyum indeksleri ve ölçüt değerleri

\begin{tabular}{lccc}
\hline Uyum indeksleri & İyi Uyum & $\begin{array}{c}\text { Kabul Edilebilir } \\
\text { Uyum }\end{array}$ & Ölçülen Değer \\
\hline RMSEA & $0 \leq \mathrm{RMSEA} \leq .05$ & $.05<\mathrm{RMSEA} \leq .08$ & .076 \\
GFI & $.90 \leq \mathrm{GFI} \leq 1$ & $.85 \leq \mathrm{GFI}<.90$ & .85 \\
CFI & $.97 \leq \mathrm{CFI} \leq 1$ & $.95 \leq \mathrm{CFI}<.97$ & .97 \\
AGFI & $.90 \leq \mathrm{AGFI} \leq 1$ & $.85 \leq \mathrm{AGFI}<.90$ & .86 \\
$\chi^{2} /$ sd & $0 \leq \chi^{2} / \mathrm{sd} \leq 3$ & $3<\chi^{2} / \mathrm{sd} \leq 5$ & 3.4 \\
\hline
\end{tabular}

Kaynak:(Meydan ve Şeşen, 2011; Şimşek, 2007).

Ölçeğin uyum indeks değerleri incelendiğinde CFI uyum indeksinin iyi, diğer uyum indekslerinin ise kabul edilebilir uyum ölçütleri içerisinde yer aldı̆̆ durum AFA'dan elde edilen sonuçların doğruluğunun DFA tarafından da desteklendiğini göstermektedir. 


\section{Uyum Geçerliği}

Ölçeğin uyum geçerliğini test etmek amaciyla ÇAÖ ve ÖÇTÖ ile elde edilen bulguların korelasyonu hesaplanmıştır. Aynı gruba uygulanan ölçekler arasında $r=.74(p<.01)$ güçlü ve anlamlı bir ilişki tespit edilmiştir. Bu durum ÇAÖ'nun uyum geçerliğini sağladığını gösteren önemli bir kanıt olarak değerlendirilebilir.

\section{Güvenirlik}

ÇAÖ'den elde edilen ölçümlerin güvenirliği için Cronbach Alpha, Spearman-Brown ve Guttman Split-Half değerleri kullanılmıştır. Buna göre Cronbach Alpha değeri .942, Spearman-Brown korelasyon değeri .882 ve Guttman Split-Half değeri .882 bulunarak .70'in üzerinde değerler almışlardır. Bu sonuç ölçeğin iç tutarlılığının, maddeler arası korelasyon değerinin ve iki yarılama güvenirlik düzeyinin kabul edilebilir ölçütlerin üzerinde olduğunu göstermektedir. Bu değerler ölçeğin güvenirliğinin yüksek olduğunu belirtmektedir.

\section{TARTIŞMA, SONUÇ ve ÖNERİLER}

Literatür incelendiğinde çokkültürlülük ve çokkültürlü eğitime yönelik tutum, alg1, bilgi vb. durumları ölçmek için geliştirilmiş ölçekler bulunmaktadır. Bu ölçekler genelde okul yöneticileri, öğretmenler ve öğretim elemanları için geliştirilmiş olup öğretmen adayları için geliştirilen bir ölçeğe rastlanılmamıştır. Literatürden ve çeşitli ölçme araçlarından faydalanılarak araştırmacı tarafından oluşturulan maddeler Dicle Üniversitesi Ziya Gökalp Eğitim Fakültesi son sınıf öğrencilerine uygulanmıştır. Yapılan AFA sonucunda ÇAÖ adı verilen ölçeğin toplam varyansın \%43.127'sini açıklayan tek boyutlu kullanmak üzere geçerli ve güvenilir bir ölçek olduğu belirlenmiștir. Maddelerin faktör yüklerinde Madde 1 (Farklı kültürden olan insanların kendi anadillerini seçmeli ders olarak ögrenebilmesi gerekir) dışında tüm maddelerin yeterli olan faktörü yüküne sahip oldukları belirlenmiştir. Madde faktör yükü .30'un altında kalan madde ölçekten çıkarılmış ve ölçek toplam 25 maddeden oluşmuştur. Yap1 geçerliği için AFA ve DFA'da benzer sonuçlar elde edilmiş ve ölçülen uyum indekslerinin ölçütler içerisinde kaldığı tespit edilmiştir. Ayrıca yapılan uyum geçerliği ve iç tutarlık, iki yarılama gibi güvenirlik analizlerinden beklenen sonuçlar çıkmıştır. Elde edilen sonuçlar 1şığında ÇAÖ’nin öğretmen adayları için kullanılabilecek geçerli ve güvenilir bir veri toplama aracı olduğu sonucuna varılmıştır.

\section{KAYNAKÇA}

Akıncı Çötok, N. (2010). Çokkültürlülük, kültürlerarasıllı ve entegrasyon tartışmaları bağlamında alman eğitiminde Türk ögrenciler: Bremen örneği. Doktora tezi. Sakarya: Sakarya Üniversitesi Sosyal Bilimler Enstitüsü.

Asan, E. (2014). Türk ve yabancl ĕgitim sendikalarının ĕgitim politikalarl ve insan yetiştirme anlayışına etkilerinin karşılaştırmalı analizi. Yüksek lisans tezi. İstanbul: Okan Üniversitesi Sosyal Bilimler Enstitüsü.

Banks, J. A. (2014). Çokkültürlü eğitime giriş. (H. Aydın, Çev.) Ankara: Anı Yayıncılık.

Başbay, A. ve Kağnıcı, D. Y. (2011). Çokkültürlü yeterlik algıları ölçeği: Bir ölçek geliştirme çalışması. Ĕgitim ve Bilim, 36(161), 199-212.

Büyüköztürk, Ş. (2014). Veri analizi el kitabı. Ankara: PegemA Yayınları.

Cattell, R. B. (1978). The scientific use of factor analysis in behavioral and life sciences. New York: Plenum.

Çelik, H. E. ve Yılmaz, V. (2013). Yapısal eşitlik modellemesi. Ankara: Anı Yayıncılık. 
Çokluk, Ö., Şekercioğlu, G. ve Büyüköztürk, Ş. (2012). Sosyal bilimler için çok değişkenli istatistik SPSS ve LISREL uygulamalarl. Ankara: PegemA Yayınc1l1k.

Doytcheva, M. (2005). Çokkültürlülük. İstanbul: İletişim Yayınları.

Ferguson, E., \& Cox, T. (1993). Exploratory factoranalysis: A users' guide. International Journal of Selectionand Assessment, 1(2), 84-94.

Gay, G. (2002). Preparing for culturally responsive teaching. Journal of Teacher Education, 53, 106116.

Gay, G. (2010). Culturally responsive teaching: Theory, research and practice. New York: Teachers College Press.

Güvenç, B. (1994). İnsan ve kültür. İstanbul: Remzi Kitabevi.

Koç Damgacı, F. ve Aydın, H. (2013). Türkiye'deki eğitim fakültelerinde görev yapan akademisyenlerin çokkültürlü eğitime ilişkin görüşleri. Dicle Üniversitesi Ziya Gökalp Eğitim Fakültesi Dergisi, 21, 314-331.

Meydan, C. H. ve Şeşen, H. (2011). Yapısal eşitlik modellemesi AMOS uygulamaları. Ankara: Detay Yayinc1lik.

Polat, S. (2012). Okul müdürlerinin çokkültürlülüğe ilişkin tutumları. Hacettepe Üniversitesi Eğitim Fakültesi Dergisi, 42, 334-343.

Ponterotto, J. G., Baluch, S., Greig T., \& Rivera, L. (1998). Development and initials score validation of the teacher multicultural attitude survey. Educational and Psychological Measurement, 58(6), 1002-1016.

Portera, A. (2008). Intercultural education in Europe: Epistemological and semantic aspects. Intercultural Education, 19(6), 481-491.

Portes, A., \& Rumbaut, R. G. (2006). Immigrant America: A portrait. California: University of California Press.

San, İ. (1983). Kültür aktarımı ve çağdaş kültür sorunu içinde sanat eğitiminin yeri. Ankara Üniversitesi Ĕ̈itim Bilimleri Fakültesi Dergisi, 2(16), 137-145.

Seçer, İ. (2013). SPSS ve LISREL ile pratik veri analizi. Ankara: Anı Yayınc1lık.

Şimşek, Ö. F. (2007). Yapısal eşitlik modellemesine giriş: Temel ilkeler ve LISREL uygulamaları. Ankara: Ekinoks Yayıncılık.

Tabachnick, B. G., \& Fidell, L. S. (2007). Using multivariate statistics. Boston: Pearson Education, Inc.

Turhan, M. (1969). Kültür değişmeleri. İstanbul: Devlet Kitapları.

Yazıc1, S., Başol, G. ve Toprak, G. (2009). Öğretmenlerin çokkültürlü eğitim tutumları: Bir güvenirlik ve geçerlik çalışması. Hacettepe Üniversitesi Eğitim Fakültesi Dergisi, 37, 229-242. 